\title{
BARRIERS TO DISCLOSE HIV STATUS TO FAMILY MEMBERS AMONG PEOPLE LIVING WITH HIV
}

\author{
Kusman Ibrahim ${ }^{1}$, Laili Rahayuwati ${ }^{2}$, Yusshy Kurnia Herliani ${ }^{1}$
}

1. Department of Medical and Surgical Nursing, Faculty of Nursing, Universitas Padjadjaran

2. Department of Community Nursing, Faculty of Nursing, Universitas Padjadjaran

\begin{abstract}
Disclosing HIV status has inhibited HIV infected persons from getting access to sufficient prevention, care, treatment, and support, which in turn can contribute to poor HIV/AIDS control. This study aims to explore the reasons underlying the barriers to disclosing HIV status to family members among people with HIV infection. This is a qualitative exploratory study. Forty participants participated in the study which was divided into five focus group discussions. They were purposively recruited from two district hospitals in West Java. FGDs were audiotape recorded with permission from participants and were verbatim transcribed. Data were analyzed qualitatively by thematic analysis technique. Four major themes emerged from the data; 1) Negative feelings about being a HIV-infected person, 2) Feeling fear of being rejected by family members, 3) Avoiding being a burden on the family, 4) Desiring to maintain a good relationship with family members. The study suggested that nurses and health care providers need to consider family as the primary source of support and encouragement for people with HIV infection. Strengthening the self-confidence of PLWH and family coping strategies needs to be more emphasized when caring for people with HIV infection particularly in the first stage after being diagnosed as HIV positive.
\end{abstract}

Keywords: Barriers, Disclose, Family, HIV Status

\section{ABSTRAK}

Mengetahui status HIV merupakan pengalaman yang mengejutkan dan penuh stres bagi seseorang yang baru didiagnosa HIV positif. Mengungkapkan status HIV ke keluarga tidaklah mudah bagi kebanyakan pasien. Penelitian ini bertujuan mengeksplorasi kendala-kendala yang mendasari orang terinfeksi HIV enggan membuka statusnya ke keluarga. Penelitian kualitatif eksplorasi ini melibatkan 40 partisipan yang dibagi ke dalam lima grup diskusi terarah. Partisipan direkrut secara purposif dari lima klinik HIV di lima rumah sakit di Jawa Barat. Atas izin partisipan, diskusi kelompok direkam dan kemudian dibuat transkrip untuk dinalisis menggunakan teknik tematik analisis. Empat tema utama muncul dari data yaitu: 1) Perasaan negatif menjadi seorang terinfeksi HIV, 2) Perasaan takut/khawatir ditolak oleh anggota keluarga, 3) Menghindari menjadi beban bagi keluarga, 4) Keinginan untuk memelihara hubungan baik dengan keluarga. Hasil penelitian ini menyarankan kepada perawat dan tenaga kesehatan lainnya untuk mempertimbangkan keluarga sebagai sumber dukungan utama bagi pasien terinfeksi HIV. Penguatan kepercayaan diri pasien untuk membuka status dan penguatan strategi koping pasien dan keluarga perlu terus dilakukan terutama pada tahap awal didiagnosis HIV positif.

Kata kunci: Hambatan, Keluarga, Kendala, Pengungkapan, Status HIV 


\section{BACKGROUND}

Nowadays, many people have become more familiar with HIV/AIDS due to the massive amount of information about HIV/AIDS spread by both electronic and printed media. However, widely available information about HIV/AIDS does not necessarily warranty a better understanding regarding HIV/AIDS, particularly amongst the general public. Stigma and discrimination faced by people living with HIV/AIDS remains unreported in many areas of society. UNAIDS (2015) noted that in $35 \%$ of countries with available data, over $50 \%$ of people reported having discriminatory attitudes towards people living with HIV infection (PLWH). HIV-related stigma and discrimination refers to prejudice, negative attitudes and abuse directed at people living with HIV and AIDS. Fear of stigma and discrimination is known as the main reason for HIV-infected people not to get tested, not to disclose their HIV status and take antiretroviral treatment $(\mathrm{WHO}, 2011$; UNAIDS, 2014). Sayles, Wong, Kinsler, Martins, \& Cunningham (2009) reported that HIV-infected people who reported experiencing high levels of stigma were over four times more likely to report poor access to care.

Stigma and discrimination can prevent HIV-infected people from disclosing their status after finding out they were HIV positive. The disclosure of HIV status among people who test positive for HIV has important implications for preventing new HIV infections and for the treatment, care and support of PLWH. Literature on HIV status disclosure among $\mathrm{PLWH}$ is dominated by research on the rates, barriers and consequences of disclosure to sexual partners, because of the assumed preventive health benefits of partner disclosure (Maman, Rooyenb, \& Groves, 2013). For example, it is reported that in India, the disclosure rate is $14 \%$ (Arun, Singh, Lodha, \& Kabra, 2009), whereas it is $13 \%$ in Nigeria (Brown, Oladokun, Osinusi, Ochigbo, Adewole \& Kanki, 2011). There are differences in HIV disclosure prevalence rates among countries which have been reported by several researchers. The higher disclosure rate observed in the resource rich countries may reflect a better education of the care-givers and understanding of the importance of disclosure (Gyamfi, Okyere, Enoch, \& Appiah-Brempong, 2017).

There are some benefits gained by PLWH when they disclose their HIV status, especially to family members. Disclosure of HIV status can lead to increased social support, improved access to treatment, and prevent further HIVrelated transmission and related complications. However, several negative effects of HIV status disclosure such as stigma, discrimination, and violence, seem to remain as the main factors for PLWH not disclosing their HIV status (Maman et al. 2013). A deep understanding of the main reasons and factors associated with HIV status disclosure from the perspective of PLWH is important to address the proper interventions of prevention, care, and support for PLWH. This study aims to investigate the barriers faced by PLWH who do not disclose their HIV status to family members.

\section{METHODS}

This is a qualitative explorative study. Data was collected after obtaining permission from the director of the hospitals where the data was collected. Ethical clearance was given by the Ethical Research Committee, University of Padjadjaran (Letter number: 087/UN6.C.10/PN/2017). Five focus group discussions (FGDs) were conducted with PLWH at the five hospital-affiliated HIV Clinics in West Java, Indonesia. Participants were recruited based on the following criteria: being HIV positive, adult, having either direct experience or support from other HIV positive persons who encounter barriers to disclosing HIV status, and willingness to participate in the study. Forty participants were involved in the five FGDs and each group consisted of 7 to 9 persons. Discussions were carried out in a convenience room arranged by the nurse who works in the clinic. The main researcher acted as a facilitator of discussion, assisted by a note taker and a general assistant. The duration of each discussion lasted about two hours. All 
participants were warmly welcomed by the researcher and team and they sat around the table. The researcher began by introducing the name of the research team, institution affiliation, purpose, estimated time and expectations of the meeting. For ethical reasons, the participants were asked to fill in and sign the informed consent form when they were ready to participate. They were also asked for their consent that during the discussion, their voice would be audio recorded. The participants were allowed to introduce themselves one by one including their name, address (not in detail), and brief history of their personal background. The main issue presented to the group was "what is it like to disclose HIV status to the family or significant others, and what are the barriers". The participants were encouraged to feel free respond to the issue. The other participants could provide comments, opinions or feelings based on their knowledge of the topic. The researchers' role was to maintain the discussion by ensuring that it was running smoothly and that all participants had an equal opportunity to express their concerns and feelings about the given topic. At the end of the session, the facilitator summarized the results of the discussion and provided rewards and appreciation to all participants for their valued contribution. Refreshments of food and drink, souvenirs, and transportation fees were given to the participants at a reasonable rate to compensate them for their participation. Data were then transcribed verbatim and analysed using thematic analysis for qualitative data. The themes that emerged from the data were checked and then reviewed by colleagues with experience in qualitative st

\section{RESULTS}

The characteristics of participants were the following: the majority of the participant's ages were between 26 and 35 years, predominantly male, Sundanese, senior high school or equivalent education level, self-employed, and had been living with HIV and receiving ART for over two years, as presented in the table 1.
Table 1. Demographic characteristics of participants $(n=40)$

\begin{tabular}{|c|c|c|}
\hline Characteristic & $\begin{array}{l}\text { Frequency } \\
\text { (f) }\end{array}$ & $\begin{array}{c}\text { Percentage } \\
(\%)\end{array}$ \\
\hline \multicolumn{3}{|l|}{ Age (years) } \\
\hline $17-25$ & 10 & 25 \\
\hline $26-35$ & 15 & 37.5 \\
\hline $36-45$ & 13 & 32.5 \\
\hline$>45$ & 2 & 5 \\
\hline \multicolumn{3}{|l|}{$\begin{array}{l}M=32.6 \quad S D=7.3 \\
R=20-51\end{array}$} \\
\hline \multicolumn{3}{|l|}{ Sex } \\
\hline Male & 23 & 57.5 \\
\hline Female & 17 & 42.5 \\
\hline \multicolumn{3}{|l|}{ Ethnic } \\
\hline Sundanese & 38 & 95 \\
\hline Other & 2 & 2 \\
\hline \multicolumn{3}{|l|}{ Education } \\
\hline Junior High & 14 & 35 \\
\hline School & & \\
\hline Senior High & 19 & 47.5 \\
\hline School & & \\
\hline $\begin{array}{l}\text { University/ } \\
\text { Academy }\end{array}$ & 7 & 17.5 \\
\hline \multicolumn{3}{|l|}{ Occupation } \\
\hline Student & 1 & 2.5 \\
\hline $\begin{array}{l}\text { Private } \\
\text { employee }\end{array}$ & 9 & 22.5 \\
\hline Entrepreneur & 11 & 27.5 \\
\hline Labour & 1 & 2.5 \\
\hline Housewife & 9 & 22.5 \\
\hline Others & 9 & 22.5 \\
\hline \multicolumn{3}{|l|}{$\begin{array}{l}\text { Length of living } \\
\text { with HIV }\end{array}$} \\
\hline$\leq 1$ years & 8 & 20 \\
\hline $1-2$ years & 9 & 22.5 \\
\hline$>2$ years & 23 & 57.5 \\
\hline \multicolumn{3}{|l|}{ Length of receiving } \\
\hline \multicolumn{3}{|l|}{ ART } \\
\hline$\leq 1$ years & 10 & 25 \\
\hline $1-2$ years & 10 & 25 \\
\hline$>2$ years & 20 & 50 \\
\hline \multicolumn{3}{|l|}{ Adherence } \\
\hline \multicolumn{3}{|l|}{ Counselling } \\
\hline Yes & 36 & 90 \\
\hline No & 4 & 10 \\
\hline
\end{tabular}

Four major themes emerged from the data; 1) Negative feelings regarding being a HIV infected person, 2) Feeling fear of being rejected by family members, 3) Avoiding being a burden on family members, 4) Desiring to maintain a good relationship with family members. Each theme will be described and presented as follows: 


\section{Theme 1: Negative feelings of being a} HIV infected person

Stigma was experienced not only from people around the PLWH such as family or general public. In many cases, stigma or negative perceptions existed originally internally from the person with HIV/AIDS themselves. They thought that the people around them would have a negative view of HIV infected people due to the many negative perceptions regarding HIV transmission (related to bad or deviant behaviours according to the norms and values of the community). In fact, those assumptions were not right at all. Some families and people within the community have a better understanding about HIV and their cultural beliefs and norms, especially the family's obligation to care for the sick family member because it is a responsibility of the family. People will see it negatively if families neglect their sick family members regardless of the types of illness suffered from including HIV infection. Based on this view, negative feelings or perceived stigma hinder the person with HIV infection from disclosing their status and even prevents them from getting support from family or community members. One participant who was HIV positive and worked as a community outreach officer for an NGO expressed the following:

“... sometimes HIV infected persons have negative feelings about themselves, they hide their status from family, spouses, and their close relatives. At least ..it is one point that made stigmatized themselves which might prevent having support from family. Whereas, based on my experience, the family support was very important in giving both physical and psychological comfort when I was sick and during recovery times..." (Participant 11, FGD-5)

\section{Theme 2: Feeling fear of being rejected by family members}

This theme was expressed by participants who hadn't disclosed their HIV positive status to their family due to feelings of worry, fear and anxiety. If their family knew about their HIV positive status then they would not accept them. This perception arose because the participants still bore witness that public stigma related to HIV/AIDS remains in existence. As a family, it was known that once one of the family members got a HIV infection, people would think that the family was spoiled by the sick member. In that case, some families made a choice not to accept the HIV-infected family member in their house. One participant said:

It is still happening ..a family brought his/her son who suffer from HIVIAIDS to the District AIDS Commission (KPA), the family said...." how come my son got HIV positive, we were not ready to accept him to live with us". The KPA officer looked confused and contacted me as a field outreach officer of a NGO, asking for help.... w was shocked because we also have not enough space or transit house to receive the patient....the family should accept him because he was part of the family..this such a story sometimes makes other new HIV infected persons fear to disclose their status to avoid rejection from their family. (Participant 8, FGD-5).

Another participant also supported the continued existence of stigma within the family as said:

"As I know, the source of diseases can come from anywhere, not only from injecting illicit drugs, or sexual misconduct, but also from married husband, or blood transfusion, ... but what I personally feel the most difficult thing was stigma from our own family which is still happening right now.." (Participant 1, FGD-2)

\section{Theme 3: Avoiding being a burden for the family}

Strong feelings about stigma was not only a concern for the participants but also for the family. Families may feel isolated and prejudiced by the community. This condition led the PLWH to keep their status private, because if their family knew that a member was HIV positive and the surrounding people knew, the family would be stigmatized. One participant said: 
The first three months after I knew my status, that was the difficult time for me, especially to deal with my parent in law who live together with me and my husband. My husband has been known by his parent, as it's response, they separated eating equipment and bath towel for my husband. I hide my HIV status for couple months though I noticed the family seem suspicious about my HIV status. I didn't care what was thought by the family, the important thing I was healthy, productive, independent and I didn't bother the family. (Participant 1, FGD-2).

Another participant expressed:

I was punished by HIV positive 5 months ago, I carried out it by myself...it was a consequence of my previous negative behaviours, I did everything by myself, my family didn't know that I got HIV infection until now...I think I am still able to handle everything and don't want to make burden to family for this time..." (Participant 9, FGD-4)

Theme 4: Desire to maintain a good relationship with family members.

Some participants noticed that stigma and discrimination still exist among family and community members. This stigma or negative perception towards people with HIV might have resulted from inadequate knowledge of HIV/AIDS. In some circumstances, media representation of HIV/AIDS has also influenced public opinion about HIV/AIDS. The presence of a HIV infected person in a family creates tension and can be seen as source of embarrassment which threatens the family reputation. Therefore, conflicts and disruptions in family relationships are sometimes inevitable. In order to maintain a good relationship with family, participants kept their HIV status private. The participants thought this might be caused by inadequate understanding among family about HIV/AIDS. One participant share her experience as follows:
"I still have a problem with my husband's family especially my mother in law. She has been given information, brochure, understanding and so on...about HIVIAIDS...but she was still ignorant and had a negative view about HIV. That's why I still keep my status private right now...I don't want to damage my relationship with my husbands' family if they know that I am an HIV positive.....but I hope she will get better understanding next time...." (Participant 1, FGD-2)

\section{Another participant also said:}

"In the beginning I kept my status only for myself, my family did not know, my neighbours also didn't know that I am HIV positive...because I believe it is good to maintain the relationship and be accepted in the family and community....till one day, a hospital officer visited my house and told me that I have to visit the Seroja clinic (the name for HIV Clinic), so my family and neighbours thought that $I$ was infected.... and as a consequence... I was expelled from family and community where I lived..." (Participant 4, FGD-4)

\section{DISCUSSION}

This study found some significant reasons for non-disclosure of HIV status, especially to family members, from the perspective of people living with HIV infection. Negative perceptions or feelings resulting from being a HIV infected person were still the main issue that inhibited PLWH from disclosing their HIV positive status. Negative feelings are often the cause of 'self-stigmatization', which prevent PLWH from exposing themselves and having good interpersonal or social relationships. A previous study by Arrey, Bilsen, Lacor, \& Deschepper (2015) found that 'self-stigmatization' was often occurred in the lives of almost all their participants. It was driven by publicly endorsed negative feelings, the chronic/incurable nature of the disease, and HIV transmission misconceptions (Arrey et al. 2015). The most striking implications of HIV self-stigmatization include reluctance to seek treatment/care and unwillingness to disclose $\mathrm{HIV}+$ status. 
Self-stigmatization could also affect personal and psychological feelings (Lindayani, Ibrahim, Wang, \& Koe, 2017).

Feeling fearful of rejection by family members was reported by many participants, especially in the beginning stage after first being diagnosed as HIV positive. This happened due to the effect of stigma that still exists amongst family members and general public. Previous studies related to the stigma experienced by PLWH on the family level revealed that HIV-infected women were often associated with amoral behaviours which led to the rejection by family especially the husbands' family (Yakhmi, Sidhu, Kaur, \& Dalla, 2014). In some cases, the study found that families were not concerned about expelling their child with HIV, HIVinfected wife was left by the husband, even community leaders were reluctant to take care of the body of HIV-infected person for funeral (Posel, 2004). Those negative reactions by family and community members resulted in feelings of fear among PLWH to disclose their HIV status.

Avoiding being a burden for the family was expressed by participants as a barrier to disclosing their HIV status. Having HIV/AIDS has caused a significant burden on the family and society. The family may suffer from the burden of care and be burdened from the psychological stress related to the stigma. Family is the first line of environment where the PLWH live, whatever happened to the PLWH as a family member will affect the family's wellbeing. Maman et al. (2013) found that some of the reasons why PLWH did not disclose their HIV status to their family were being worried about their mother's health and desire to protect their family's emotional and physical well-being.

Maintaining good relationships with family members has been a major concern among PLWH in this study. They avoid causing damage to the relationships by exposing their HIV status to family. Stigma resulting from HIV might be a threat for family well-being and family member conflicts could happen. Audet, McGowan, Wallston, \& Kipp (2013) found that PLWH who did not disclose their HIV status cited reasons such as they thought that if they disclose their status they might lose family support, loss of friends, and even losing their job. It is understandable since the family support is very important for PLWH and for other family member to maintain their existence.

\section{CONCLUSION AND RECOMMENDA TIONS}

This study revealed four major themes reflecting the barriers of HIV status disclosure to family member. The themes are negative feelings of being a HIV infected person, feeling fear of being rejected by family members, avoiding making a burden for family and desiring to maintain a good relationship with family members. Findings of the study suggested that nurses and other health care providers need to consider family as the primary source of support and encouragement for people with a HIV infection. Improving the self-confidence of PLWH and family coping strategies needs to be more emphasized in caring for people with HIV infection particularly in the first stage after being diagnosed as HIV positive.

\section{ACKNOWLEDGMENT}

We would like to sincerely thank the Ministry of Research, Technology, and Higher Education of the Republic Indonesia for providing funding, and thank the Universitas Padjadjaran for all support and facilitation. A special thank you to all participants and the research team for invaluable contributions throughout the study.

\section{REFERENCES}

Arrey, A.E., Bilsen, J., Lacor, P., \& Deschepper, R. (2015). "People don't know that I'm HIV positive": self-stigma in the lives of subSaharan African migrant women in Belgium. Global Advanced Research Journal of Medicine and Medical Science, 4(3):21-131

Arun, S., Singh, A.K., Lodha, R., \& Kabra, S. (2009). Disclosure of the HIV 
infection status in children. Indian Journal of Pediatric, 76:805-8.

Audet, C.M., McGowan, C.C., Wallston, K.A., \& Kipp, A.M. (2013). Relationship between HIV stigma and self-isolation among People Living with HIV in Tennessee. PLoS ONE 8(8): e69564. doi:10.1371/ journal.pone.0069564

Brown, B.J., Oladokun, R.E., Osinusi, K., Ochigbo, S., Adewole, I.F., \& Kanki, P. (2011). Disclosure of HIV status to infected children in a Nigerian HIV care program. AIDS Care, 23:10538.

Gyamfi, E., Okyere, P., Enoch, A., \& Appiah-Brempong, E. (2017). Prevalence of, and barriers to the disclosure of HIV status to infected children and adolescents in a district of Ghana. BMC International Health and Human Rights, 17:8 DOI 10.1186/s12914-017-0114-6

Lindayani, L., Ibrahim, K., Wang, J.D., \& Koe, N.Y. (2017). Independent and synergistic effects of self- and public stigmas on quality of life of HIVinfected persons. AIDS Care. DOI: 10.1080/09540121.2017.1396282

Maman, S., van Rooyenb, H., \& Grovesa, A.K. (2013). HIV status disclosure to families for social support in South Africa. AIDS Care, DOI: 10.1080/09540121.2013.819400
Posel D. (2004) Sex, death and embodiment: Reflections on stigma of AIDS in Agincourt, South Africa. Paper presented at the symposium on 'Life and Death in a Time of AIDS: The Southern African Experience', WISER 14-16 October 2004.

Sayles, J.N., Wong, M.D., Kinsler, J.J., Martins, D., \& Cunningham, W.E. (2009). 'The association of stigma with self-reported access to medical care and antiretroviral therapy adherence in Persons Living with HIV/AIDS'. Journal of General Internal Medicine. 24(10)

UNAIDS. (2015). On the Fast-Track to end AIDS by 2030: Focus on location and population. Geneva: UNAIDS

World Health Organization (WHO). (2011). Global HIV/AIDS Response: Epidemic update and health sector progress towards Universal Access: Progress report 2011. Geneva: WHO

UNAIDS. (2014). Guidance note: Reduction of HIV-related stigma and discrimination. Geneva: WHO

Yakhmi, S., Sidhu, B. S., Kaur, B., \& Dalla, E. K. (2014). Study of HIV related stigma in people living with HIV/AIDS (PLHA): Role of gender differences. Indian Journal of Scientific Research, 5(2), 35. 